\title{
KOMIK IKLAN KOMIK
}

\author{
Wibowo \\ Desain Komunikasi Visual \\ Fakultas Seni Rupa ISI Yogyakarta \\ Wibowo_dkvisi@yahoo.com
}

\begin{abstract}
Comics are a form of visual art that uses still images and is arranged in such a way in several panels that make up the fabric of the story. While Cergam is a picture that has served as an illustration in a series of stories. The types of comics that are rarely included in large groups of comics, namely Advertising Comics. Like Indie Comics, it's quite surprising why comic designers don't think about it. For certain types of products that are not too serious in advertising information, comics turn out to be a potential medium. Especially for the target audience of young people who prefer visual and entertaining images such as comics. Maybe because it is considered advertising was born from business needs. Not a pure work of art. Therefore "comic advertisements" are included in the category of public service media. Some famous comic artists are often "used" by producers to draw advertisements. The audience immediately recognized the painter by the way he told stories, the character's figures and the style of his strokes.
\end{abstract}

Keywords: Comics, public service ads, advertising comics

\section{PENDAHULUAN}

"Awas lo. Tungguin aja. Gua panggilin ORANG TUA gua..” Ancam seorang anak sambil berlari kepada seorang preman yang habis memukulinya. Si preman gondrong yang nampak sangar itupun dengan enteng meladeni : "Panggilin sini!! Gua gak takut!". Beberapa saat kemudian si anak datang bersama se ORANG TUA. "Hallouw! Sapa orang tua itu dengan ramah dan senyum dibibirnya. Si preman terkejut bukan main. Ia seperti melihat hantu. Wajahnya mendadak kecut. Tubuhnya gemetar dan berkeringat dingin. Ia seperti pernah melihat sosok kakek tua itu. Tiba tiba ia ingat. Orang itu mirip sekali dengan gambar ORANG TUA yang ada di botol kemasan Anggur Kolesom cap
Orang Tua. Janggut dan alisnya yang putih. Matanya yang sipit. Kepala botaknya, dan baju kuningnya yang khas biksu Shaolin. Namun ketakutan si preman itu mendadak sirna, begitu bersalaman dengan kakek yang ramah itu.

"Lah itu ORANG TUA lo ?" Tanya si preman pada anak itu. "Kenapa gak bilang sih.... berarti kita "saudaraan" bro.. he.he..he.." Lanjut si preman merajuk, sambil garuk garuk kepala. $\mathrm{Si}$ anak pun gembira. Kesan bangga nampak diwajahnya. "Lah, gua juga gak tau. Peace Bro! He..he.. he.."

Cerita diatas adalah storyline dari iklan Anggur Kolesom cap Orang Tua. Iklan ini berbentuk komik digital pendek karya Reza 
Mustar. Produk minuman anggur adalah produk yang masuk kategori produk "Akrobat" (Alkohol, kondom, rokok dan obat obatan), yang sulit untuk beriklan. Selain tidak semua media boleh mengiklankannya, juga terdapat regulasi peraturan yang rumit dari BPOM RI, untuk konten iklannya. Maka, pemasang iklan produk ini harus cerdas dan kreatif, supaya tetap komunikatif terhadap target audiencenya, namun juga aman dari aturan itu. Mari kita lihat. Tidak ada ajakan sama sekali dari iklan ini untuk membeli atau mengkonsumsi produk ini. Logo atau brandname, yang biasa ditampilkan di iklan produk lan juga tidak ada. Dengan menghadirkan "Orang Tua" dengan profil yang lengkap, sebagai ikon produk Anggur cap Orang Tua itu, cukup membuat audience mengenali dan tersenyum, karena lucu. Pendekatan ini dalam strategi iklan sering disebut Retentive stage, atau reminding. Dipilihnya komik ini juga strategi media yang jitu. Komik yang berbentuk visual jelas menarik perhatian, dan memiliki stopping power yang kuat. Media planningnya juga tepat, karena dipasang di medsos (facebook, instagram), yang akrab dengan target audiencenya, anak muda.

Pada komik yang lain, masih dalam tema yang sama, digambarkan dua orang laki laki bertato yang sedang bersitegang. Laki laki pertama memperkenalkan diri sebagai
“Geboy Skin”, dengan sikap dan pandangan mata yang menantang. Laki laki
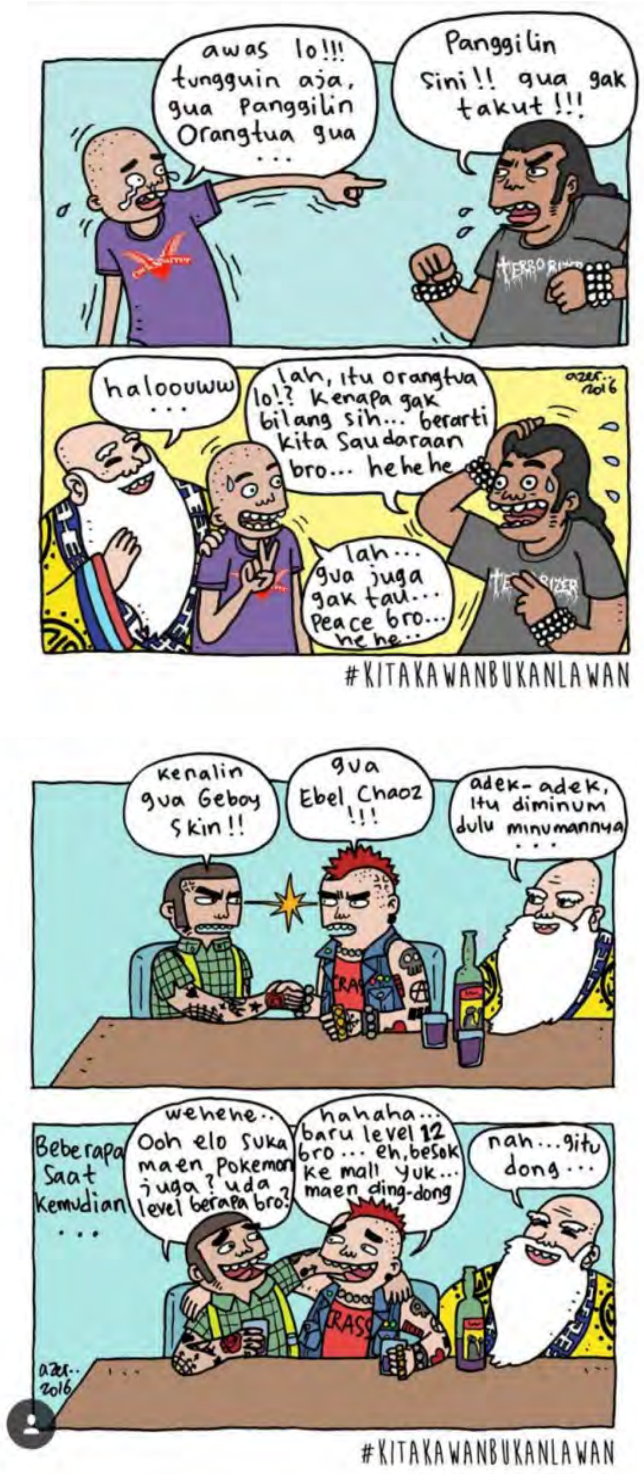

Gambar 1 Komik Iklan Anggur Kolesom Orang Tua. Sumber :

https:/www.instagram.com/komikazer/?hl=en

Pada komik yang lain, masih dalam tema yang sama, digambarkan dua orang laki laki bertato yang sedang bersitegang. Laki laki pertama memperkenalkan diri sebagai “Geboy Skin”, dengan sikap dan pandangan 
mata yang menantang. Laki laki ke dua yang bertampang tidak kalah sangar dengan potongan "Punkrock" langsung menjawab : "Gua Ebelchaos !!" Nama Geboy Skin dan Ebelchaos adalah tokoh film kartun Pokemon yang berseteru. Saat itu tiba-tiba muncul "Orang Tua" yang mirip ikon Anggur Orang Tua. Melihat situasi tegang itu, si kakek dengan sikap ramah dan senyum lebar mempersilahkan mereka untuk minum: "Adik adik, itu diminum dulu minumannya”. Di atas meja sudah tersedia 1 botol Anggur cap Orang Tua dan dua gelas kosong. Entah kenapa, suasana menjadi berubah menjadi cair. Ketegangan pun sirna. "We he he...Ooh elo suka maen Pokemon juga ? Uda level berapa Bro?" tanya Si Tato, yang dijawab oleh Si Punkrock : "Ha ha ha... baru level 12 Bro... Eh Besok ke Mall yuk.. Maen ding dong.." Melihat itu, si kakek (ORANG TUA) itupun nampak senang :"Naah..gitu.." komentarnya..... Pada bagian bawah komik itu tertulis hashtag: \#KITAKAWANBUKANLAWAN. Komik yang kedua inipun menunjukkan ketokohan si orang tua, yang berperan sebagai pendamai yang sangat disegani. Strategi dan tujuan dari komik ini adalah : mengangkat image produk. Menyentuh alam bawah sadar audience, melalui suasana kondusif dan damai yang diciptakan "Orang Tua" itu. Jika image positif sudah terbentuk, masalah penjualan produk adalah masalah kecil.

\section{Kelebihan dan Kekurangan Iklan Komik.}

Untuk membahas kelebihan dan kekurangan Iklan komik, ada baiknya dikenali dulu mengenai keberadaan komik, beberapa jenis komik, pengertian komik iklan efektivitas penggunaan komik dalam iklan dan sebagainya, sehingga bisa dipahami apa saja kelebihan dan kekurangan iklan komik.

Di tahun 1989, dalam buku Comics and Sequential Art, Will Eisner men definisikan komik sebagai "Susunan gambar dan katakata untuk menceritakan sesuatu atau mendramatisasi ide." Sedangkan Scott McCloud menyebutnya: "Komik adalah gambar-gambar dan lambang-lambang lain yang 'terjukstaposisi' dalam urutan tertentu, bertujuan untuk memberikan informasi dan atau mencapai tanggapan estetis dari pembaca." Dengan demikian jika didefinisikan secara sederhana, komik adalah suatu bentuk karya seni yang menggunakan gambar-gambar tidak bergerak yang disu -sun sedemikian rupa sehingga membentuk jalinan cerita. Komik dapat diterbitkan dalam berbagai bentuk, mulai dari strip dalam koran, dimuat dalam majalah, hingga berbentuk buku tersendiri. Dalam pokok bahasan mengenai komik, sering rancu dengan "cergam" atau cerita bergambar. Padahal 
keduanya memiliki esensi yang berbeda. Cerita bergambar adalah cerita yang menjadi inti ceritanya adalah ada pada narasi, sedangkan gambar hanya sebagai ilustrasi pelengkap. Gambarnya hanya sebagai ilustrasi dari cerita yang ada dan tidak terjungtaposisi (tersejajar -kan), tetapi hanya menceritakan salah satu adegan dalam sebuah cerita. Untuk membedakan dengan dua jenis karya visual yang lain, yaitu kartun dan karikatur, berikut dijelaskan mengenai terminologi ke empatnya. Komik adalah suatu bentuk karya seni visual yang menggunakan gambar-gambar tidak bergerak dan disusun sedemikian rupa dalam beberapa panel sehingga membentuk jalinan cerita. Bedanya dengan kartun, kartun adalah "gambar yang berisi sindiran, kritikan, cerita jenaka, atau humor dan digambar dalam satu panel". Sementara karikatur adalah " kartun yang mendeformasi bentuk lahiriah seseorang dengan tujuan tertentu". Sedangkan Cergam adalah gambar yang telah berfungsi sebagai illustrasi dalam suatu rangkaian cerita (http://mbokmenik. wordpress.com )

\section{Jenis Komik}

Secara fungsional, bisa disebutkan beberapa jenis komik, seperti yang disebutkan oleh 'Jagoan Komik', sebagai berikut:

\section{Buku Komik (Comic Book)} Alunan gambar-gambar, tulisan dan cerita dikemas dalam bentuk sebuah butkan buku (terdapat sampul dan isi). Buku Komik (Comic Book) ini acap kali disebut sebagai komik cerita pendek, yang biasanya dalam Buku Komik berisikan 32, 48 atau 64 halaman, dimana didalamnya berisikan isi cerita, iklan, dan lainlain. Buku Komik seperti ini bisa didapatkan di toko -toko buku atau toko-toko komik maupun lapak-lapak. Buku Komik (Comic Book) itu sendiri terbagi lagi menjadi:

\section{Komik Kertas Tipis (Trade Paperback)}

Buku komik ini berukuran seperti buku biasa, tidak terlalu lebar dan besar. Walau berkesan tipis namum bisa juga dikemas dengan menggunakan kualitas kertas yang baik/bagus sehingga penampilan/penyajian buku ini terlihat menarik. Apalagi dengan gambar dan warna yang cantik, membuat buku komik ini sangat digemari. Dari dalam negeri, bisa disebutkan contoh komik dari jenis ini seperti : Gundala, Godam, Si Buta Dari Gua Hantu, Lamaut, Kapten Bandung, Caroq, Gina, Gunturgeni, Blacan, Zantoro, dan lain lain. Dari luar negeri, 
misalnya komiknya Marvel dan DC Comics.

\section{Komik Majalah (Comic Magazine)}

Buku komik berukuran seperti majalah (ukuran besar), biasanya menggunakan tipe kertas yang tebal dan keras untuk sampulnya. Dengan ukuran yang besar tersebut tentunya dengan misalkan 64 halaman bisa menampung banyak gambar dan isi cerita. Contoh: Tintin, Lucky Luke, Asterik. Semuanya dari luar negeri.

2. Komik Novel Grafis (Graphic Novel)

Biasanya isi ceritanya lebih panjang dan komplikasi serta membutuhkan tingkat berpikir yang lebih dewasa untuk pembacanya. Isi buku bisa lebih dari 100 halaman. Bisa juga dalam bentuk seri atau cerita putus.

\section{Komik Potongan (Comic Strip)} Artinya penggalan-penggalan gambar yang disusun/dirangkai menjadi sebuah alur cerita pendek. Namun isi ceritanya tidak terpaku harus selesai disitu bahkan bisa juga dijadikan suatu cerita bersambung/berseri. Biasanya terdiri dari 3 hingga 6 panel atau sekitarnya. Komik Potongan (Comic Strip) ini biasanya disodorkan dalan tampilan harian atau mingguan disebuah surat kabar, majalah maupun tabloid/buletin. Penyajian isi cerita juga dapat berupa humor/banyolan atau cerita yang serius yang asik untuk disimak setiap periodenya hingga tamat.

Contoh: Panji Koming di surat kabar Kompas dan Gibug (Komik Strip yang dijadikan buku saku)

\section{Komik Tahunan (Comic Annual)} Bila pembuat komik sudah dalam skup penerbit yang serius, si penerbit akan secara teratur/berskala (misalkan setiap tahun atau setiap beberapa bulan sekali) akan menerbitkan bukubuku komik baik itu cerita putus maupun serial. Contoh dari dalam negeri seperti: M\&C Gramedia, PMK, Marizan, Terant, BumiLangit, Jagoan Comic, dsb, dan dari luar negeri: Marvel Comics, DC Comics, dan sebagainya.

\section{Album Komik (Comic Album)} Para penggemar bacaan komik baik itu komik karikatur maupun komik strip dapat mengkoleksi (hasil guntingan dari berbagai sumber media bacaan), dimana hasil koleksiannya dikumpulkan dan disusun rapih (pengkripingan) menjadi sebuah budelan/album bacaan. 
6. Komik Online atau Komik Digital (Webcomic)

Selain media cetak seperti surat kabar, majalah, tabloid dan buletin, media Internet juga dapat dijadikan sarana dalam mempublikasikan komikkomik. Dengan menyediakan situs web maka para pengunjung/pembaca dapat menyimak komik. Dengan menggunakan media Internet jangkauan pembacanya bisa lebih luas (diseluruh dunia yang memiliki koneksi internet dapat mengaksesnya) dari pada media cetak.

\section{Buku Instruksi dalam format} Komik (Instructional Comics)

Tidak sedikit sebuah panduan atau instruksi sesuatu dikemas dalam format Komik, bisa dalam bentuk Buku Komik, Poster Komik, atau tampilan lainnya. Pengguna/Pembaca akan lebih mudah cepat mengerti bila melihat alunan gambar dari pada harus membaca prosedur-prosedur dalam bentuk tulisan. Selain itu dapat menjadi lebih menarik dan menyenangkan.

\section{Rangkaian Ilustrasi (Storyboard)}

Biasanya didalam dunia perfilman maupun periklanan, sebelum melangkah dalam pembuatan film/iklan akan lebih mudah berkerjanya bila dibuatkan Rangkaian Ilustrasinya terlebih dahulu, biasanya Rangkaian Ilustrasi ini dibuat dalam bentuk gambar, dan sudah tentu rangkaian ilustrasi gambar tersebut disusun menjadi sebuah rangkaian yang bisa disebut komik. Namun tidak usah jauh-jauh kedalam dunia perfileman/iklan, sebelum para komikus membuat komik sudah pasti terlebih dahulu membuat sebuah Rangkaian Ilustrasi (Storyboard) nya, setelah itu baru diproses penggambaran, penintaan, pewarnaan dan penataan tampilan (layout). sumber:

http://www.jagoancomic.com, diakses pada 28 Juli 2017

\section{Komik Iklan Lembaga Pendidikan}

Lembaga pendidikan, jarang sekali mengiklankan dirinya. Mereka hanya membuat pengumuman penerimaan mahasiswa baru. Kalaupun ada, akan terasa aneh dan tidak etis. Karena lembaga lembaga itu seharusnya berorientasi pada pembangunan sosial, pengabdian masyarakat, atau mencerdaskan bangsa. Padahal mereka butuh sosialisasi atas program kegiatan mereka. Mereka butuh dana. Mereka butuh konsumen, dan konsumenpun butuh jasa pendidikan. Ada cara tersendiri untuk 
promosi, atau publisitas. Yaitu dengan public relation, pariwara, advertorial, atau "iklan terselubung". Untuk target audience remaja atau lulusan sekolah menengah, komik iklan diyakini cukup efektif untuk mempromosikan lembaga pendidikan. Selain menarik, pesan yang disampaikan juga cukup komunikatif dan informatif. Sebuah lebaga pendidikan desain, Akademi Desain Visi Yogyakarta (sekarang STSRD VISI) beberapa tahun yang lalu mencoba beriklan lewat komik di majalah Aneka Yess dan Hai. Hasilnya cukup efektif. Lebih dari 20 orang menelpon, menghubungi lewat email, dan mengunjungi website lembaga tersebut. Hal itu karena ilustrasi dan copy writing dari komik tersebut cukup baik dan komunikatif.

Iklan berwarna yang bertitle "generasi Kreatif" ini terdiri dari 6 panil pada 2 lembar (dobble page) majalah. Inti ceritanya adalah kekaguman si adik pada karya desain grafis
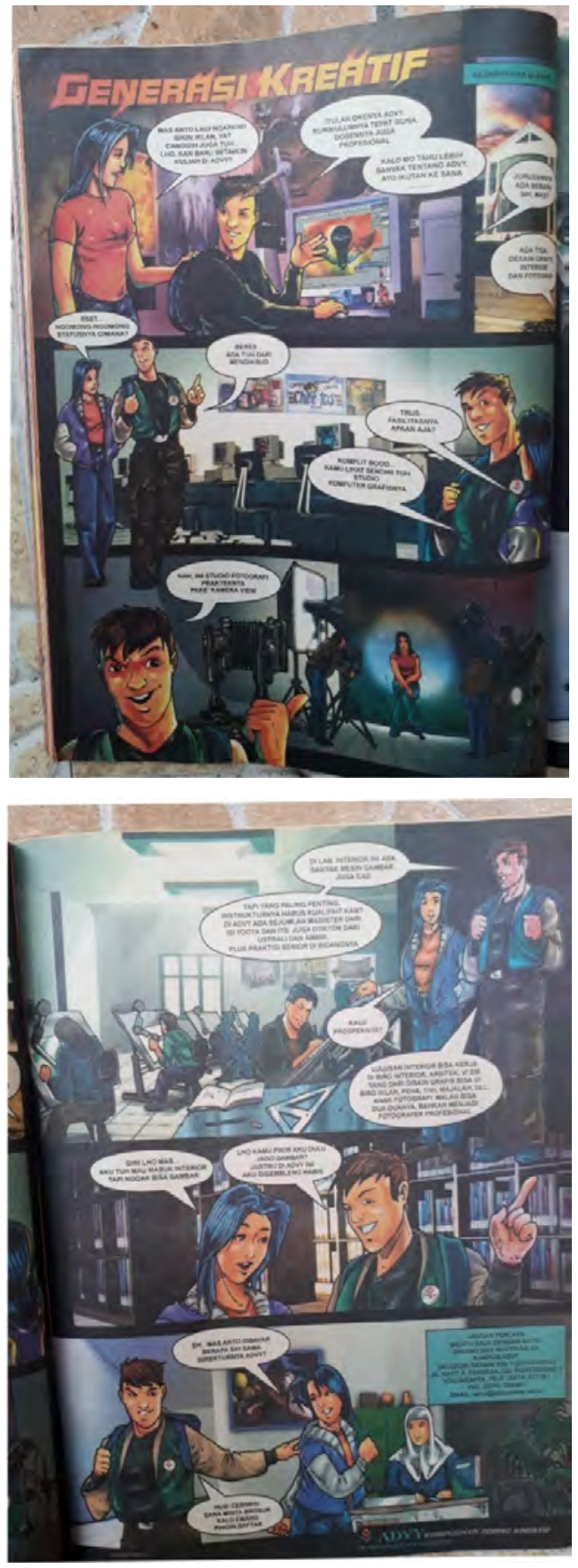

Gambar 2

Sumber : ANEKAyess! Mei 2006, p.42-43

desain grafis yang lagi digarap sang kakak di kamarnya, yang dilanjutkan dengan kunjungan mereka ke kampus ADVY. Sambil berkeliling kampus, Anto, sang kakak menjelaskan berbagai hal tentang studio komputer grafis, fotografi, interior, dan 
sebagainya. Bahkan tentang status lembagapun dibahas disini. Penjelasan ini berakhir pada panel ke enam, yang menampilkan closing word: "Jangan langsung percaya pada Anton. Dapatkan informasi ke kampus ADVY di...." dan seterusnya, dan diakhiri dengan tagline : "Kampusnya Orang Kreatif"

\section{Komik Indie}

Dalam berbagai tulisan mengenai komik baik di dalam negeri, baik di media cetak maupun online, Komik Indie tidak dimasukkan sebagai salah satu jenis komik. Hal ini diakui oleh pegiat komik sekaligus komikus, Sweta Kartika, karena dalam pengertian umum, komik selalu diterbitkan oleh penerbit yang bertanggung jawab, sehingga materi, mutu gambar, jalan cerita dan lain lain sudah teruji kualitasnya. Sedangkan komik Indie, adalah komik yang tidak berorientasi pada bisnis. (Kartika: 2016). Distribusinya hanya melalui pameran, atau orang perorang. Teknis cetaknya kadang hanya difoto copy. Sebutan untuk genre komik ini adalah komik alternatif, komik gerilya, komik underground hingga populer disebut komik indie, sebuah kependekan kata independen. Mengapa demikian ? Karena penciptanya punya idealisme dan kebebasan berkarya yang tak terbatas

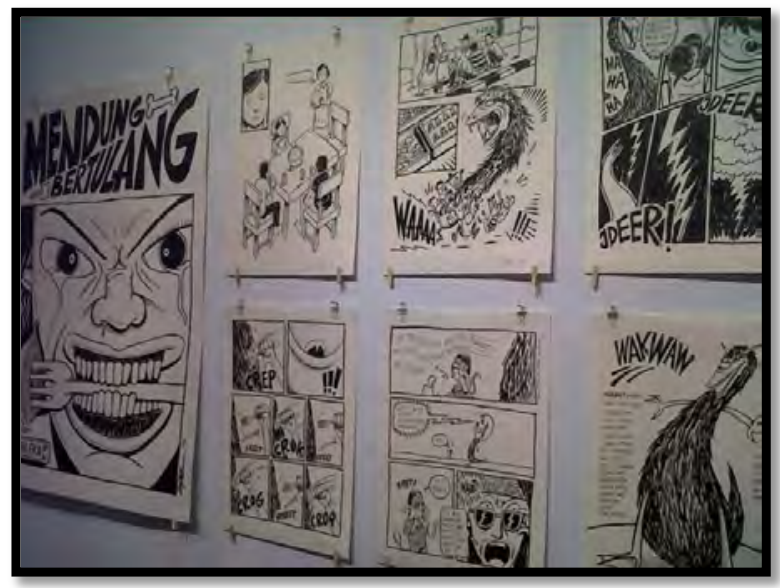

Gambar 3

Sumber :

aorinusantara.or.id/newsline/27119/retrospektifkomik-indie-menapaktilasi-komik-indie-indonesiasatu-dekade

kebebasan berkarya yang tak terbatas, sehingga kadang terkesan "liar", kasar atau tidak etis. Pada saat itu memang komik jenis ini bergerak beriringan dengan film dan musik yang mempunyai semangat yang sama, melawan dan menjadi antitesis dari major atau mainstream.

Pada ulang tahunnya yang ke sepuluh, Akademi Samali, salah satu komunitas komik di Indonesia, memamerkan koleksi-koleksi indie yang telah berhasil dikumpulkan dari kurun waktu 1995 sampai 2015, dalam acara Retrospektif Komik Indie

Komunitas yang digagas oleh Beng Rahadian S.Sn ini memang sangat konsern pada pertumbuhan komik Indie, salah satu genre komik yang sejak dulu dianggap sepele. Dari serangkaian kegiatan (pameran, seminar, 
workshop, lomba) yang diadakan oleh AS ini, audience mendapatkan pemahaman yang lengkap tentang komik indie.

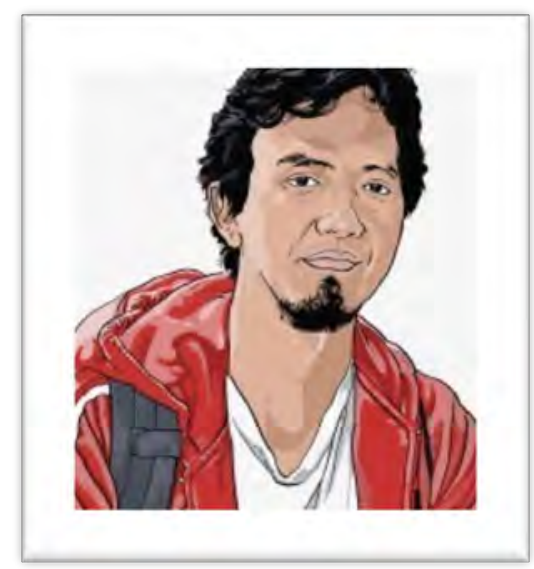

Gambar 4 Beng Rahardian : bengrahadian.com

Komik indie telah mengingatkan bahwasanya ihwal komik kadangkala bukan hanya urusan rupiah, namun juga merupakan ruang dalam imajinasi masyarakat yang tidak boleh dibiarkan kosong. . "Definisi indie sejak semula memang beragam. Pada 1990-an sampai awal 2000-an definisi indie yang dominan adalah gerakan yang bertumpu pada komik fotokopian yang bisa dieksplorasi sebagai sebuah medium khas di dalam seni printing. Jadi, sudah ada bibit yang membatasi indie semata sebagai moda produksi dan distribusi alternatif 'sebelum' masuk ke mainstream.

\section{Komik Iklan (Comic Ad)}

Satu lagi jenis komik yang jarang dimasukkan dalam kelompok besar komik, yaitu Komik Iklan. Seperti halnya Komik
Indie, cukup mengherankan kenapa para penulis komik tidak menggagas hal itu. Padahal Komik Iklan pada saat sekarang ini sudah tak terhitung banyaknya. Diluar maupun di dalam negeri. Baik digital maupun konvensional. Barangkali karena dianggap iklan itu lahir dari kebutuhan bisnis. Tidak murni karya seni. Komik iklan sendiri terdiri dari Komik Iklan Komersial dan Komik Layanan Masyarakat (Comic ad dan comic ad public service)

\section{Komik Iklan Komersial: Beriklan melalui komik.}

Produk yang sangat gemar beriklan dengan komik adalah produk obat-obatan, seperti Napacin, Mixagrip, Promag, Antangin. Selain obat obatan, produk lain yang banyak menggunakan komik adalah produk makanan anak anak, seperti: Taro, Beng beng, Milkuat susu Enfagrow, dan Fullo. Produk makanan anak-anak sering menggunakan maskot (hero) pada kemasannya. Maskot inilah yang sering menjadi tokoh utama pada komik dan iklan tv nya. Anak anak sebagai konsumennya dengan cepat akan mengenali maskot idolanya itu. Selain media konvensional seperti media cetak dan merchandised, media internet juga makin marak favorit bagi pemasangan iklan komik. Pihak brand bisa saja membuat karakter sendiri sebagai perwujudan brand 
tersebut dan membuat cerita komik dari karakter tersebut, atau membuat cerita dengan "meminjam" karakter komik lain. Di Indonesia sudah ada beberapa brand yang menggunakan komik sebagai media exposure untuk beriklan. Seperti UC Browser dan Fullo yang membuat konten komik dari maskotnya. Selain itu ada juga komik dari Dompet Dhuafa yang menampilkan karakter Si Bedil. Beberapa pemilik website atau webblog, memanfaatkan situsnya sebagai alat komersial. Salah satunya adalah PIONICON Blog. Pada menu utama atau homepagenya, Pionicon langsung menawarkan kepada pengunjungnya : "Beriklan dengan komik ? Begini caranya !’. Homepage tersebut juga memasang 3 contoh komik strip, dengan maskot "Si Juki" yang terkenal itu. Maskot Si Juki ini memang ditawarkan bersama maskot yang lain seperti : Om Hebring, Si Bedil, Tuti \& Friend, Yusya, dan Little Mince. Masing masing mewakili karakter yang khas. Brand tinggal memilih saja karakter yang cocok, tergantung pencitraan yang ingin dibangun.

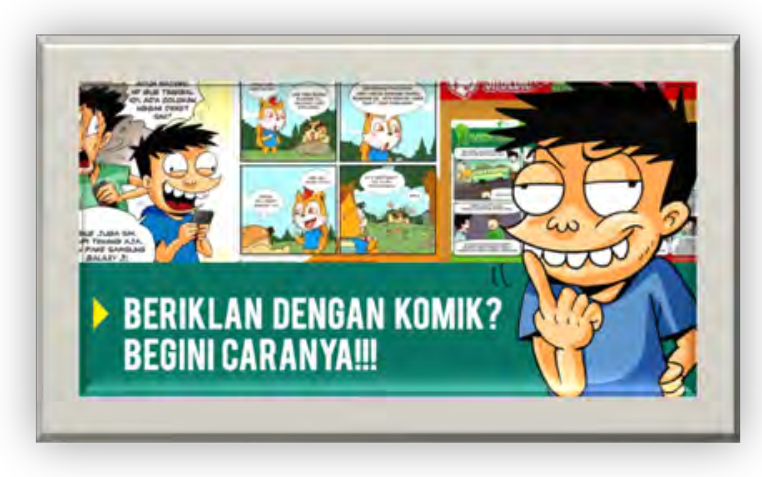

Gambar 5 Sumber : PIONICON Blog, Januari 2016

Biasanya dalam sebuah komik strip, sang komikus menyediakan beberapa tempat bagi produk untuk menaruh logo untuk beriklan sebagai sponsor dalam komik tersebut. Karakter fiksi biasanya hanya tampil dalam media komik, game, animasi, maupun merchandising. Banyak karakter fiksi dari komik, game serta animasi yang memiliki popularitas cukup besar. Popularitas tinggi dari para karakter ini ternyata menarik para pemilik brand untuk menggunakan berbagai karakter fiksi ini sebagai model iklan.

Banyak karakter fiksi yang kini telah membintangi berbagai macam iklan maupun dijadikan model dari kampanye kreatif sebuah produk. Ada karakter komik yang hadir membintangi sebuah iklan video, ada juga karakter yang muncul dalam packaging sebuah produk. Beberapa karakter-karakter berbasis IP menjadi model iklan berbagai brand ternama, misalnya: 


\section{DC Comics}

Komik superhero asal Amerika Serikat yang juga cukup terkenal ada karakter-karakter superhero terbitan DC Comics. Pada tahun 2014, pihak DC Comics melakukan kolaborasi cross-over dengan game Scribblenauts rilisan Warner Bros. Interactive Entertainment.

\section{Spongebob Square Pants}

Spongebob SquarePants merupakan karakter ciptaan Stephen Hillenburg yang menjadi karakter utama serial animasi di jaringan Nickelodeon. Tingginya popularitas karakter Spongebob ini membuat berbagai brand tertarik membuat iklan dengan Spongebob. Salah satu brand yang membuat iklan dengan Spongebob dalam media animasi dan komik ini adalah Burger King.

\section{Pokemon}

Salah satu franchise karakter yang sangat terkenal di dunia adalah Pokemon. Popularitas seri Pokemon dan karakterkarakternya sudah sangat tinggi dengan rilisnya berbagai game, film, serta animasi dari franchise ini. Selain dalam game dan animasi, Pokemon juga memproduksi komik , hasil kolaborasi dengan brand brand besar.

\section{Boboi Boy}

Perkembangan industri komik dan animasi di negara tetangga kita, Malaysia juga mengalami pertumbuhan yang pesat. Salah satu serial animasi yang sangat terke- nal dari negara tersebut adalah Boboi Boy. Boboi Boy merupakan serial animasi buatan Nizam Razak yang diproduksi oleh Animonsta Studio. Serial ini telah me- luncurkan 3 musim seri animasi dan sebuah film animasi layar lebar. Para karak- ter dalam seri Boboi Boy ini juga pernah membintangi beberapa komik iklan

\section{Si Juki}

Penggunaan karakter fiksi sebagai bintang iklan ternyata tidak hanya dilakukan di luar negeri saja. Si Juki, salah seorang karakter komik anti-mainstream asal Indonesia juga pernah membintangi berbagai iklan dalam bentuk komik. Sudah ada banyak brand yang beriklan menggunakan karakter Si Juki mulai dari game online, operator seluler, makanan ringan, mie instan hingga ponsel pintar.

\section{Komik Iklan Lewat Instagram}

Sementara itu, sejak tahun 2014, banyak komikus Indonesia yang mulai menggunakan media Instagram sebagai perpanjangan tangan untuk showcase karya mereka. Sweta Kartika misalnya, komikus Nusantara Ranger, Grey \& Jingga, dan H20, serta Sheila Rooswita Putri, komikus Cerita si Lala dan Komik Kriuk, ter-masuk diantara mereka yang mulai memanfaatkan Instagram untuk tujuan ini di tahun 2014 dan awal 2015. Perkembangan selanjutnya menjadi menarik karena ternyata Instagram juga mam- pu 
membuka pintu bagi para komikus dan illustrator yang lebih junior untuk menerbitkan karya mereka. Dalam hal ini Instagram menjadi platform yang sangat jujur untuk memproyeksikan sambutan publik terhadap suatu karya. Komik strip Instagram merupakan salah satu content creation yang menjanjikan untuk pasar Indonesia karena tiga alasan; Pertama, masih rendahnya minat baca masyarakat Indonesia, $(0,001 \%$ menurut survey Unesco). Banyak orang yang akan lebih suka melalap konten jenis ini daripada membaca caption yang panjang. Kedua, sebagian besar pengguna internet di Indonesia mengakses dunia maya lewat perangkat seluler. Format social media seperti Instagram memungkinkan pengguna internet untuk mengaksesnya bahkan dengan paket kuota termurah sekalipun. Ketiga, sebagian besar dari pengguna Instagram di Indonesia berada pada range usia 18-40. Ini merupakan range usia yang produktif dengan daya beli yang baik, sehingga sangat menarik bagi pelaku berbagai kategori bisnis. Namun demikian, media yang multi talented dan sangat familiar dengan anak muda itupun tak luput dari kendala, ketika menjadi media exposure untuk komik iklan. Dalam hal ini, Andreas Trijaya, dalam blognya The Great Andre, yang diposting pada 26 Februari 2017, dan bertajuk "Dari Komik ke Meja Makan", memberi beberapa tips bagi pemasang komik iklan di Instagram sebagai berikut :

Pertama, komik strip Instagram memiliki keterbatasan berupa oleh ukuran media dan kualitas visual. Karenanya, komunikasi via platform ini lebih baik menia ekposureitik beratkan pada fungsi sebuah produk atau jasa, baik secara teknis maupun sosial. Kedua, sangat wajar jika semakin banyak follower seorang comic stripper, semakin kebanjiran order untuk membuat postingan berbayar. Hanya saja, jika presentase iklan dan karya dalam akunnya tidak proporsional, ia akan kehilangan kredibilitasnya sebagai seniman. Ada baiknya memilih komikus yang konsisten dengan gaya maupun pesan moral dan sosial dalam karyanya.

Ketiga, pertimbangkan untuk bekerja sama dengan seorang komikus dalam jangka waktu tertentu, untuk lebih dari satu postingan. Selain menunjukan konsistensi pesan, si komikus juga punya ruang lebih luas untuk mengeksplorasi brandnya.

\section{KOMIK IKLAN LAYANAN MASYARAKAT.}

Jumlah iklan layanan masyarakat yang berupa komik memang tidak lebih banyak daripada komik iklan komersial. Namun Komik iklan ILM ini cukup efektif karena umumnya disponsori oleh brand besar yang bertujuan memperoleh image atau pencitraan 
yang baik. Setidaknya dalam hal media placement atau frekuensi pemasangannya. Beberapa contoh diantaranya misalnya : komik dakwah /agama, komik politik, dan komik pendidikan.
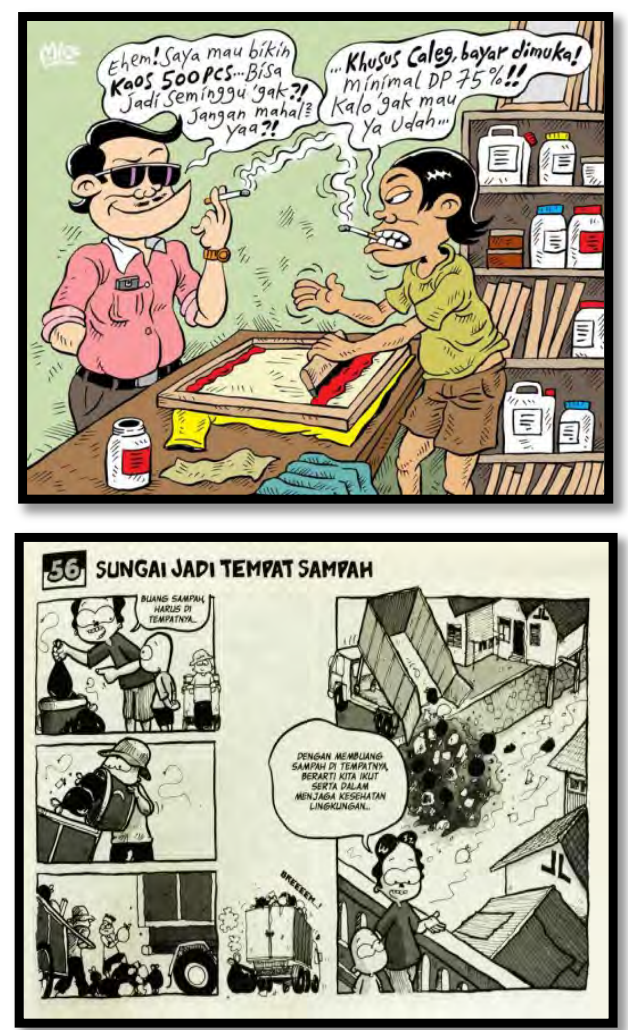

\section{Gambar 6}

Sumber : Mypagerank.net Sitemap Submitter : 2016

\section{REFERENSI:}

[1] Andreas Trijaya, (dalam blog The Great Andre): "Dari Komik ke Meja Makan" diposting 26 Februari 2017

[2] Burhan Nurgiyantoro, 2005.Sastra anak (pengantar pemahaman dunia anak). Yogyakarta: Gadjah Mada University Press.

[3] Dody Kusumanto, Retrospektif Komik Indie: Menapaktilasi Komik Indie Indonesia Satu Dekade, Jakarta, 9 May 2015
[4] McCloud, Scout, 2001. Understanding Comic, Jakarta. Kepustakaan Populer Gramedia,

[5] Sudarmaji, dkk. 2010. Teknik Bercerita. Yogyakarta: PT Kurnia Kalam Semesta

http://id.wikipedia.org

http://www.jagoancomic.com

http://www.hansteru.wordpress.com

http://www.brokyoutline.multiply.com

http://www.kribowz.blogspot.com 